
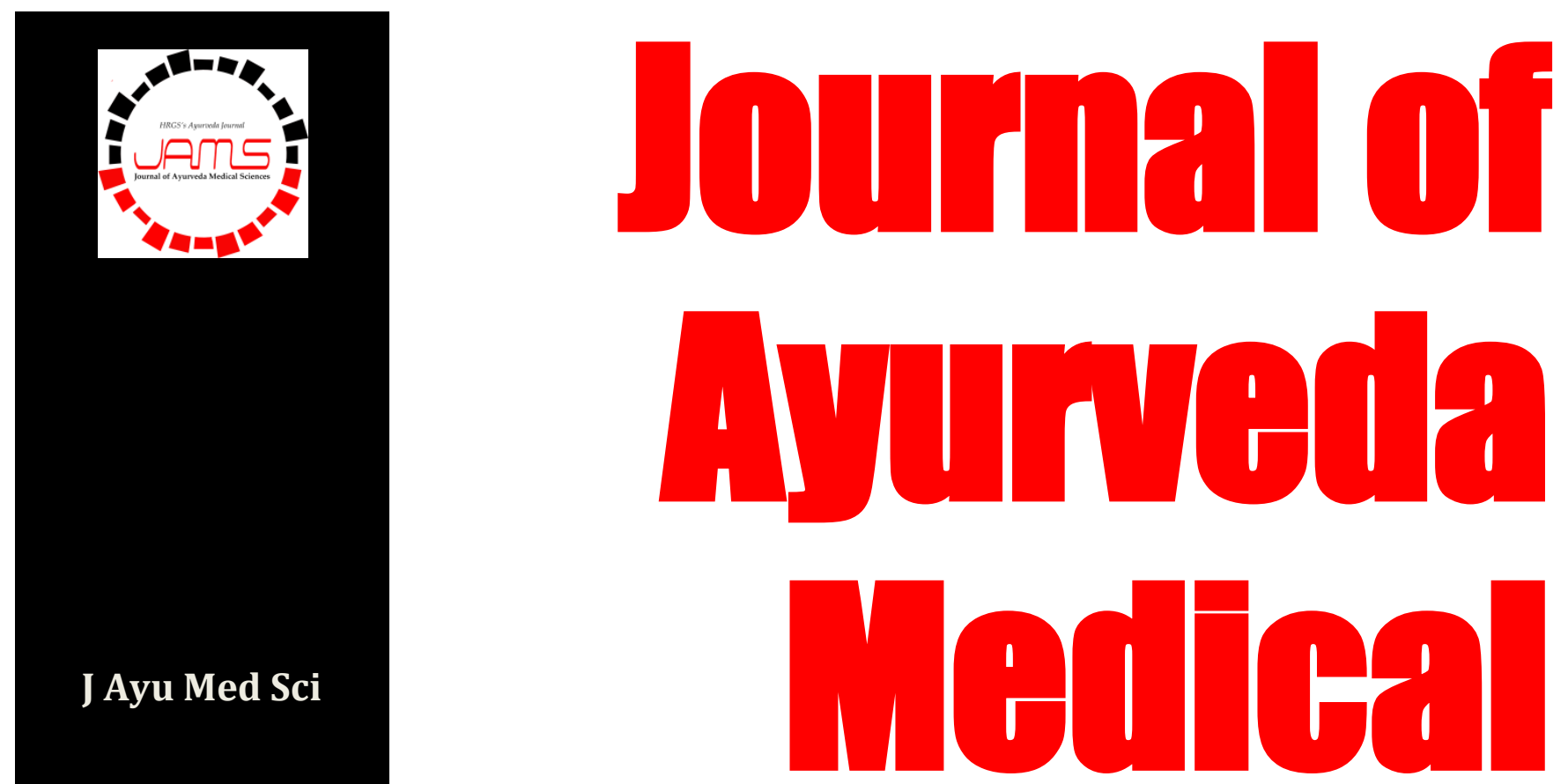

Quarterly Journal for

Rapid Publication

of Researches

in Ayurveda

and Other Traditional

Medicines

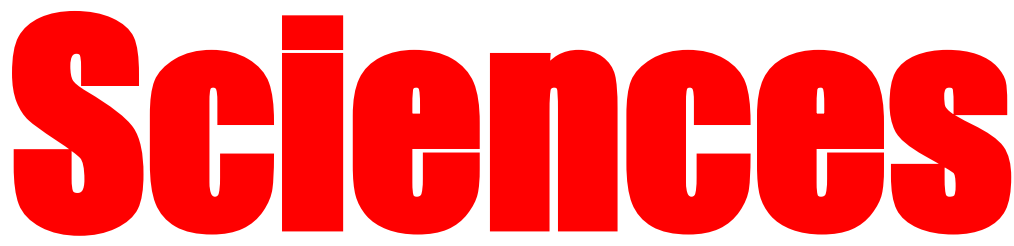

www.jayumedsci.com

ISSN 2456-4990

\title{
Ayurveda Management of Syrigomyelia - A Single Case Study
}

Patient presented withdysphagia, regurgitation,vertigo, repeated spitting, one sided weakness with numbness and mild pain and hearing loss. MRI showed a syrinx extending from cervico-medullary junction to D12 and CSF flow study showed Backward flow with low mean velocity. She diagnosed case of Arnold Chairi malformation syringohydromyelia Type 1. Patient was diagnosed as kaphaavritapranavayu along with shiromarmaabhighata and treated with panchkarma therapies and shamans medicationsprimality for 5 months then follow up for every 3 month. Significant improvement was found in both classical symptoms as well as in MRI, CSF flow study and x-rays reports.

Agarwal et al. 


\section{Ayurveda Management of Syringomyelia - A single Case Study}

\section{Ankita Agarwal*, Asit Kumar Panja}

Department of Basic Principles, National Institute of Ayurveda, madhav Vilas Palace, Amer Road, Jaipur, Rajastan 302002, India.

\section{ABSTRACT}

Background: Syringomyelia is a disorder in which a fluid filled cyst forms within the spinal cord and causes a wide variety of neuropathic symptoms. No permanent cure has been found yet in modern science to treat this disease. However different Panchkarma therapies along with oral drugs mentioned in Ayurveda texts have been found to be effective in this disease. In present case report a patient diagnosed with Arnold Chairi malformation syringohydromyelia Type 1 was treated with Ayurveda modalities. According to Ayurveda patient was diagnosed as kapha-avrita-pranavayu along with shiromarmaabhighata. Method: A 26years old female patient with the symptoms of dysphagia, regurgitation of food through nose, vertigo, repeated spitting thick sputum, weakness of right upper and lower limb associated with numbness and mild pain and hearing loss was given Ayurveda treatment. The features were assessed on the basis of classical signs and symptoms mentioned in Ayurveda. Panchakarma therapies such as karna-purana, shiropicchu etc. along with oral medications according to the line of treatment of above mentioned Ayurveda diagnosis were administered for 5 months. Improvement was assessed on the basis of relief in patients's symptoms along with MRI reports and CSF flow study. Follow up was taken to evaluate the sustainability of the result. Result: Significant improvement was found in both classical signs and symptoms as well as in MRI and CSF flow study. There were significant relief in all mentioned complaints of patient apart from hearing loss. Size of syrinx reduced markedly in size in current MRI reportand CSF flow study. Conclusion: Present case study shows that the symptoms of syringomyelia can be successfully treated in accordance with the principles of Ayurveda.

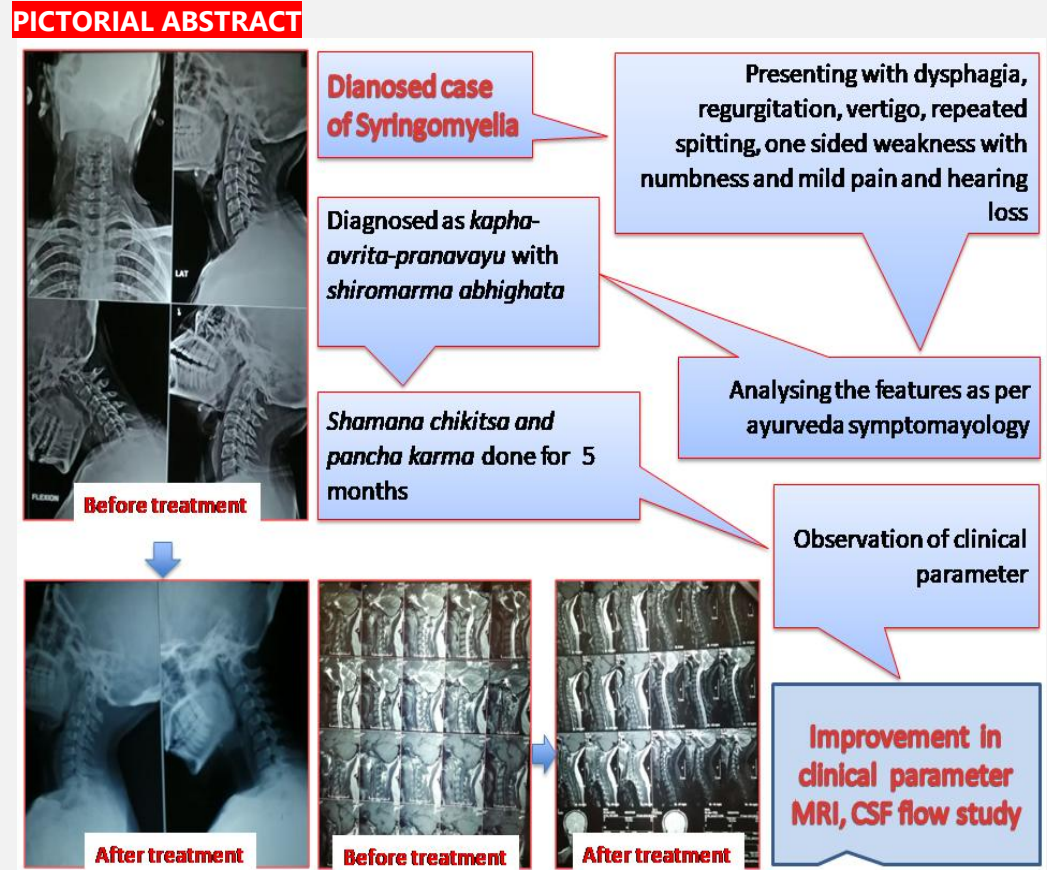

ARTICLE HISTORY Received 25.04.2019 Accepted 06.08.2019

CORRESPONDENCE Dr. Ankita Agarwal, PG Scholar, Department of Basic Principles, National Institute of Ayurveda, Madhav Vilas Palace, Amer Road, Jaipur, Rajastan 302002, India. Email: chinuagarwal5@gmail.com

CITE THIS RESEARCH AS Agarwal A, Panja AK. Ayurveda Management of Syringomyelia - A single Case Study. J Ayu Med Sci 2018;3(4):437-42.

DOI 10.5530/jams.2018.3.25

\section{INTRODUCTION}

Syringomyelia refers to a disorder in which a fluid filled cyst called as 'syrinx'develops within the spinal cord. This syrinx may damage to the spinal cord and as a result of this damage patient experiences severe pain, abnormal sensations and other neurological symptoms. ${ }^{[1]}$ Syringomyelia can be categorized broadly in three forms namely congenital brain defects, injury of the spinal cord and idiopathic syringomyelia. ${ }^{[2]}$ The most common form of syringomyelia is found associated with congenital brain abnormalities. ${ }^{[3]}$ Chiari malformation type 1 falls in this first category. Type 1 occurs when the lower part of the cerebellum (called the cerebellar tonsils) gets displaced downwardly through the foramen magnum and may form a syrinx which causes pressure on the spinal cord. ${ }^{[4]}$ Chiari malformation type 1 is associated with group of symptoms such as neck pain, unsteady gait (problems with balance), poor hand coordination (fine motor skills), numbness and tingling of the hands and feet, dizziness, difficulty swallowing, sometimes accompanied by gagging, choking and vomiting. Vision problems (blurred or double vision), speech problems such as hoarseness occur usually in the late childhood or adulthood. According to the reports, prevalence of syringomyelia is about 8.4 cases per 100,000 people. ${ }^{[5]}$ However, till now there is no permanent cure of this disease. Some surgical procedures such as duroplasty, shunt placement etc. are adopted to restore the normal CSF flow and reduce the pressure on spinal cord. These procedures carry the risk of spinal cord injury and may not effective in all. Hence, there is a need to understandthis disease 
through the wisdom of other clinical sciences for finding out safer treatment. A patient diagnosed as Chairi malformation - I syringomyelia was treated with Ayurveda modalities. Patient's symptoms were interpreted with the classical symptoms of kapha-avrita-prana-vayu along with shiro-marma-abhigata. ${ }^{[6,7]} \mathrm{A}$ case is being presented which was treated as per the treatment principle of avarana-chikitsa and shiro-marma-abhigatachikitsa.

\section{CASE REPORT}

A 26 year old female patient diagnosed as 'arnold chiari malformation syringohydromyelia type 1' came to OPD, Dept of Basic Principles, National Institute of Ayurveda, Jaipur. She presented with the symptoms like dysphagia, regurgitation of food through nose, occasional voice change, vertigo, repeated spitting of thick sputum (more than 25 to 30 times in a day), hearing loss, weakness in right upper and lower limb associated with numbness and mild pain. In addition to that she also complained of pain in the neck and face region. Ayurvedic treatment was started on 23/08/2018 after explaining the prognosis clearly. Past sequences of presentation and chronology of the manifestations are given in Table 1.

\subsection{Therapeutic focus and assessment}

In this case, shiropichu, karnpurana with dhanwantarm oil were given as patient was showing the symptoms of shiro-marma-abhigata. The procedures mentioned in shiro-marma-abhigatachikitsa were continued up to 5 months. Dhanwantarm oil ${ }^{[14]}$ has vata mitigating property and does not vitiate kapha due to its anabhishyanditva. After that, nasya with karpasthyadi oil for srotoshodhana and abyanga with dhanwantarm oil for vatanashana were included in previous mentioned procedures. Apart from procedures, oral medicines such as nimba-amritadieranda oil ${ }^{[15]}$ for mridu-virechana, dashmoola decoction, ${ }^{[16]}$ shilajatu $^{[17]}$ etc were started.

\section{Table 1. Timeline of the case}

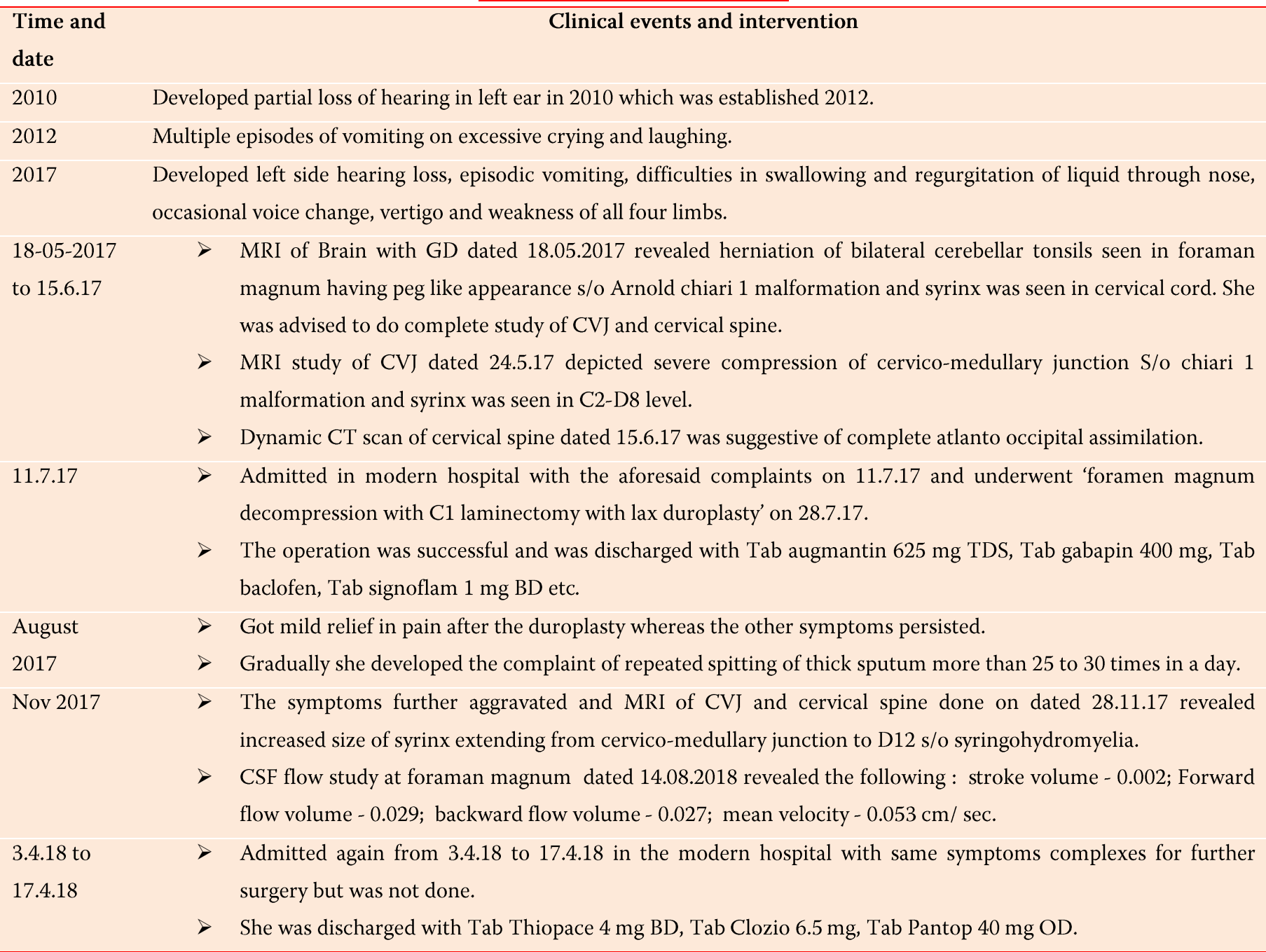


At this stage, patient approached for Ayurvedic treatment in order to avoid surgery and to reduce the fluid content in the syrinx.

\subsection{Ayurvedic diagnosis}

The presentation and Ayurveda assessment are given in Table 2.

Table 2. Features as per Ayurveda

\begin{tabular}{ll}
\hline \multicolumn{1}{c}{ Presentation } & \multicolumn{1}{c}{ Feature as per Ayurveda } \\
\hline Difficulty in swallowing and regurgitation of food through nose & Annaadanakarmavikriti, vikrata pranavayukarma $^{[8]}$ \\
Repeated spitting of thick sputum & Ati-sthivana $^{[9]}$ \\
Hearing loss in left side of ear & Shrutihani $^{[10]}$ \\
Feeling weakness in right upper and right lower limbs & Hasta-padachestahani $^{[1]]}$ \\
Pain in right upper and right lower limb & Hasta-padaruja $^{[12]}$ \\
Numbness of limbs & Hasta-padasuptata $^{[10]}$ \\
Pain in the neck region and face & Gandaruka $^{[12]}$ \\
Impairment of one half the body (the face along with half of the & Ardita $^{[11]}$ \\
body) associated with pain, discomfort and improper motor and & \\
sensory functions & \\
Change in voice & Gadgadtavam $^{[11]}$ \\
Vertigo & Bhrama $^{[11]}$ \\
Loss of appetite & Aruchi $^{[13]}$ \\
\hline
\end{tabular}

\section{Table 3. Treatment given}

\begin{tabular}{|c|c|c|c|c|c|}
\hline Date & Treatment given & Details of treatment given & Dose & $\begin{array}{l}\text { Anupana and } \\
\text { sevana kala }\end{array}$ & Duration \\
\hline \multirow[t]{6}{*}{ 23.8.18 } & Shamanchikitsa & Nimbaamritadi oil & $5 \mathrm{ml} \mathrm{OD}$ & $\begin{array}{l}\text { Warm milk, } \\
\text { nishakala }\end{array}$ & 28 days \\
\hline & & Musta Paniya & $\begin{array}{l}6 \mathrm{~g} \text { in } 2 \mathrm{l} \\
\text { reduced to } 1.5 \mathrm{l}\end{array}$ & Whole day & 28 days \\
\hline & Food & Proyagikatarpana & $25 \mathrm{~g}$ & $\begin{array}{l}\text { With honey mix in } \\
100 \mathrm{ml} \text { water - } \\
\text { during breakfast }\end{array}$ & 28 days \\
\hline & Panchkarma & & & & \\
\hline & Abyanga & Dhanwantaram oil - whole body massage & As required & Prate kala, ananna & 28 days \\
\hline & Karnapurna & Karpassthyadi oil & 2 drops & Prate kala, ananna & 28 days \\
\hline \multirow[t]{8}{*}{20.09 .18} & Panchkarma & & & & \\
\hline & Abyanga & Dhanwantarm oil - whole body massage & As required & Prate kala, ananna & 14 days \\
\hline & Pratimarsha Nasya & Karpassthyadi oil & 2 drops & Prate kala, ananna & 14 days \\
\hline & Shiropicchu & Kaspassthyadi oil & As required & Prate kala, ananna & 14 days \\
\hline & $\begin{array}{l}\text { Lepa (over neck and affected } \\
\text { area up to the level of syngx) }\end{array}$ & Kolakulathadilepa & As required & Butter milk & 14 days \\
\hline & Shamanachikitsa & Nimbaamritadi oil & $5 \mathrm{ml} \mathrm{OD}$ & $\begin{array}{l}\text { Warm milk, } \\
\text { nishakala }\end{array}$ & 14 days \\
\hline & & Musta Paniya & $\begin{array}{l}6 \mathrm{~g} \text { in } 2 \mathrm{l} \\
\text { reduced to } 1.5 \mathrm{l}\end{array}$ & Whole day & 14 days \\
\hline & Food & Proyagikatarpana & $25 \mathrm{~g}$ & $\begin{array}{l}\text { With honey \& } 100 \\
\text { ml water - during } \\
\text { breakfast }\end{array}$ & 14 days \\
\hline \multirow[t]{3}{*}{04.10 .18} & Panchkarma & Same as before & & & 28 days \\
\hline & Shamanachikitsa & & & & \\
\hline & & Haritaki powder & $5 \mathrm{~g} \mathrm{BD}$ & Jaggery, ananna kala & 28 days \\
\hline
\end{tabular}




\begin{tabular}{|c|c|c|c|c|c|}
\hline & & $\begin{array}{l}\text { Dashmool decoction }(12 \mathrm{~g} \text { yavakuta }= \\
\text { boiled in } 400 \mathrm{ml} \text { water reduced to } 200 \mathrm{ml})\end{array}$ & $100 \mathrm{ml} \mathrm{BD}$ & In empty stomach & 28 days \\
\hline & Food & Proyagikatarpana & $25 \mathrm{~g}$ & $\begin{array}{l}\text { With honey and } 100 \\
\text { ml water - during } \\
\text { breakfast }\end{array}$ & 28 days \\
\hline \multirow[t]{5}{*}{01.11 .18} & Panchkarma & Same as before & & & 45 days \\
\hline & Shamanachikitsa & & & & 45 days \\
\hline & & Haritaki powder & $5 \mathrm{~g} \mathrm{BD}$ & Jaggery, ananna kala & 45 days \\
\hline & & $\begin{array}{l}\text { Dashmool decoction }(12 \mathrm{~g} \text { yavakuta }= \\
\text { boiled in } 400 \mathrm{ml} \text { water reduced to } 200 \mathrm{ml})\end{array}$ & $100 \mathrm{ml} \mathrm{BD}$ & In empty stomach & 45 days \\
\hline & Food & Proyagikatarpana & $25 \mathrm{~g}$ & $\begin{array}{l}\text { With honey and } 100 \\
\text { ml water - during } \\
\text { breakfast }\end{array}$ & 45 days \\
\hline \multirow[t]{3}{*}{ 20.12.18 } & Panchkarma & Same as before & & & 14 days \\
\hline & Shamanachikitsa & Kshirbala oil (101 avarti) & 10 drops & Milk, after breakfast & 14 days \\
\hline & & Shudhashilajatu & $250 \mathrm{mg}$ & Milk in morning & 14 days \\
\hline \multirow[t]{4}{*}{03.01 .18} & Panchkarma & Same as before & & & 14 days \\
\hline & Shamanachikitsa & Shudhashilajatu & $250 \mathrm{mg}$ & Milk in morning & 14 days \\
\hline & & Haritaki powder & $5 \mathrm{~g} \mathrm{BD}$ & Jaggery, ananna kala & 14 days \\
\hline & & $\begin{array}{l}\text { Dashmool decoction }(12 \text { g yavakuta }= \\
\text { boiled in } 400 \mathrm{ml} \text { water reduced to } 200 \mathrm{ml})\end{array}$ & $100 \mathrm{ml} \mathrm{BD}$ & In empty stomach & 14 days \\
\hline \multicolumn{6}{|c|}{ Follow up treatment } \\
\hline \multirow[t]{5}{*}{ 17.1.19 } & Panchkarma & & & & \\
\hline & Abyanga & Dhanwantarm oil - for whole body massage & As required & $\begin{array}{l}\text { Prate kala, ananna } \\
\text { kala }\end{array}$ & 90 days \\
\hline & Karnapurna & Karpassthyadi oil & 2 drops & $\begin{array}{l}\text { Prate kala, ananna } \\
\text { kala }\end{array}$ & 14 days \\
\hline & Shamanachikitsa & Kshirbala oil (101 avarti) & 10 drops & Milk, after breakfast & 90 days \\
\hline & & Shudhashilajatu & $250 \mathrm{mg}$ & Milk in morning & 90 days \\
\hline \multirow[t]{5}{*}{ 14.4.19 } & Panchkarma & & & & \\
\hline & Abyanga & Dhanwantarm oil - for whole body massage & & $\begin{array}{l}\text { Prate kala, ananna } \\
\text { kala }\end{array}$ & 90 days \\
\hline & PratimarshaNasya & Karpassthyadi oil & 2 drops & $\begin{array}{l}\text { Prate kala, ananna } \\
\text { kala }\end{array}$ & 14days \\
\hline & Shamanachikitsa & Kshirbala oil (101 avarti) & 10 drops & Milk, after breakfast & 90 days \\
\hline & & $\begin{array}{l}\text { Dashmoolksirapaka }(6 \mathrm{~g} \text { yavakuta = boiled } \\
\text { in } 100 \mathrm{ml} \text { water plus } 100 \mathrm{ml} \text { milk = reduced } \\
\text { to milk i.e. } 100 \mathrm{ml})\end{array}$ & $\begin{array}{l}100 \mathrm{ml} \mathrm{BD} \text {; every } \\
\text { time prepared } \\
\text { fresh }\end{array}$ & In empty stomach & 90 days \\
\hline \multirow[t]{4}{*}{ 25.7.19 } & Panchkarma & & & & \\
\hline & Abyanga & Dhanwantarm oil - for whole body massage & & $\begin{array}{l}\text { Prate kala, ananna } \\
\text { kala }\end{array}$ & 90 days \\
\hline & Shamanachikitsa & Kshirbala oil (101 avarti) & 10 drops & Milk, after breakfast & 90 days \\
\hline & & $\begin{array}{l}\text { Dashmoolksirapaka }(6 \mathrm{~g} \text { yavakuta }=\text { boiled } \\
\text { in } 100 \mathrm{ml} \text { water plus } 100 \mathrm{ml} \text { milk = reduced } \\
\text { to milk i.e. } 100 \mathrm{ml})\end{array}$ & $\begin{array}{l}100 \mathrm{ml} \mathrm{BD} \\
\text { every time } \\
\text { prepared fresh }\end{array}$ & In empty stomach & 90 days \\
\hline
\end{tabular}

Patient was not on allopathic medication during this treatment period. For assessment, symptoms of kaphaavritapranavayu along with shiromarmaabhigata and MRI reports were used. 
A significant improvement was noted in this case in both classical signs and symptoms as well as in MRI. There were improvement in symptoms such as bhrama (vertigo), suptata, daurbalya and ruja in dakhniahasta and pada (weakness, numbness, pain in right upper and lower limb), annaadanakarmavikrati (regurgitation of food), gadgadtavam (change in voice), aruchi (loss of appetite) and gandaruka (pain in neck). However, there was no significant relief in shrutihani (hearing loss). Notable improvement was noticed in MRI reports which has been presented as mentioned in Table 4 .

\section{Table 4. Comparative chart of improvement after treatmen}

\begin{tabular}{llll}
\hline & Before treatment & $\begin{array}{l}\text { After treatment (dated } \\
\text { 06.01.2019) }\end{array}$ & Follow up (22.07.19) \\
\hline $\begin{array}{llll}\text { MRI cervical } \\
\text { spine }\end{array}$ & $\begin{array}{l}\text { Increased size of syrinx extending from } \\
\text { cervico-medullary junction to D12 s/o } \\
\text { syringohydromyelia (dated 28.11.17) }\end{array}$ & $\begin{array}{l}\text { Hyper intense signal intensity is } \\
\text { seen within the cord extending } \\
\text { from C2 to D6 level suggestive of }\end{array}$ & $\begin{array}{l}\text { Evidence of central CSF signal } \\
\text { intensity is seen in the visualised }\end{array}$ \\
& & syrinx & suggestive of syrinx \\
CSF flow study & Stroke volume - 0.002; & CSF flow velocity is normal at the & Not done as patient was normal \\
at foraman & Forward flow volume - 0.029; & foramen magnum in the systolic & \\
magnum & Backward flow volume - 0.027; Mean & and diastolic phase & \\
& velocity- $0.053 \mathrm{~cm} / \mathrm{sec}$. & & \\
& (dated 14.08 .18$)$ & &
\end{tabular}

Follow up was taken to evaluate the sustainability of the result

\section{DISCUSSION}

Pranavayu resides in brain and moves in chest and throat. It regulates the functions related to heart, intellect, and sense organs such as expectoration, sneezing, and belching inspiration and swallowing of food. ${ }^{[8]}$ However when it gets vitiated by other dosha or obstructed (avrita) by kaphadosha it cannot execute its action properly and also shows adventitious symptoms such as vomiting, nausea, loss of appetite. ${ }^{[6]}$ Untreated condition leads to further vitiation of pranavayu which affects its residing place brain (shira $)^{[7]}$ and causes symptoms mentioned in shiromarmaabhigata like ardita, vertigo (bhrama), hearing loss, daurbalya, etc. ${ }^{[1]}$

In this case, patient started with complain of nausea, vomiting, hearing loss, regurgitation of food through nose, which reflect the symptoms of vitiated pranavayu. However, in due course of time, these symptoms got aggravated and some other symptoms mentioned in shiromarmaabhigat started to appear such as ardita, bhramam, daurbalya. For restoring the proper flow and functions of pranavayu, it is necessary to remove the obstruction of kapha. It is done by the treatment principle of avaranachikitsa along with shiromarmaabhigatachikitsa. According to Avaranachikitsa, the treatment modalities having anabhishyanadi but snigdha, cleansing properties (to clean the passage of the srotas) and mriduvirechan, rasayana, shilajatu should be used. ${ }^{[17]}$ As per the treatment principle of shiromarmaabhigata, abyanga, svedana, nasyaandvasti should be done. ${ }^{[18]}$ Hence, in this case barring vasti, both avarnachikitsa and shiro-marmaabhigatachikitsa mentioned above have been adopted.

At present, patient is under observation and on oral treatment and no complications are noted during follow up. Also, there is no worsening of previous complaints of patient which encourages for further treatment planning and research in this disease through Ayurveda prospective.

\subsection{Probable brief mode of action of treatment}

Dhanwantaram oil is used for abyanga. It contains mainly dashamula which mitigates vata without aggravating kapha due to its anabhishyandiva property. Karpasasthyadi thailam, mentioned in arditachikitsa, is used for karnapurana, nasya and shiropichu. Karpassthyadi oil contains mainly karpasa, balamoola and kulatha which has srotoshodhana property but also neutralizes vata.

Initially mustapaniya is given for pachana and srotoshadhana which helps in removing the avarana of kapha. Nimbaamritadieranda oil is given for vataanulomana as it contains eranda oil and guggulu. It helps in restoring the fellow of prana-vayu. Subsequently gudaharitaki is given as mriduvirechana. Dashamula decoction is given for vatanashana. Rasayanachikitsa is adopted as patient is having symptoms of marmaabhighata. Shilajatu mentioned in avaranachikitsa is used in later phase as it removes the avarana and act as a rasayana.

In food, prayogikatarpana is used which contains mainly yava powder, pachaniyadravya and is having laghu property. It removes avarana to some extent. 


\section{CONCLUSION}

The above mentioned case study shows that the symptoms of syringomyelia can be successfully treated in accordance with the basic principles of Ayurveda. This study can support in further research of the treatment of syringomyelia with the help of Ayurveda principles.

PATIENT CONSENT The authors certify that they have obtained all appropriate patient consent forms. In the form the patient has given consent for clinical information to be reported in the journal. The patient understands that her name and initials will not be published and due efforts will be made to conceal their identity, but anonymity cannot be guaranteed.

\section{FINANCIAL SUPPORT Ni}

CONFLICTS OF INTEREST There are no conflicts of interest.

ACKNOWLEDGEMENT The authors thank the patient and her family without whom the study would not have been accomplished.

CONTRIBUTORS Ankita Agarwal did the literature survey, data acquisition from various sources and design. Panja Asit K contributed to conceptualization of the topic, intellectual content and manuscript editng. The clinical study has been conducted by Ankita Agarwal and Panja Asit K.

\section{Reference}

1. http://en.m.wikipedia.org Accessed on 09.08.2019

2.

https://www.betterhealth.vic.gov.au/health/ConditionsAndTreatments/ syringomyeliaAccessed on 09.08.2019

3.

https://www.betterhealth.vic.gov.au/health/ConditionsAndTreatments/ syringomyelia Accessed on 09.08.2019

4. https://www.ninds.nih.gov/Disorders/Patient-Caregiver-

Education/Fact-Sheets/Chiari-Malformation-Fact-Sheet Accessed on 09.08.2019

5. http://emedicine.medscape.com>article Accessed on 09.08.2019

6. Acharya Jadavji Trikamji (Editor), Revised Edition. Charaka Samhita by Agniveshwith Commentary by Chakrapanidatta, Chikitsasthan Chapter 28, verse 222: Varanasi: ChaukhambhaSurbharatiPrakashan 2011: p.626.
7. Acharya Jadavji Trikamji (Editor), Revised edition. Charaka Samhita by Agniveshwith Commentary by Chakrapanidatta: Sidhisthan Chapter 9, verse 4, Varanasi: Chaukhambha Surbharati Prakashan, 2011: p.716.

8. Bhisagacharya Harishashtri Paradkar (Editor), Reprint edition. Ashtanga Hridayam by Vagbhata with commentaries Sarvangasundara of Arundatta and Ayurvedarasayana of Hemadri: Sutrasthana Chapter12, verse 4-5; Varanasi: Krishnadas Academy, 2000: p.193.

9. Bhisagacharya Harishashtri Paradkar (Editor), Reprint edition. Ashtanga Hridayam by Vagbhata with commentaries Sarvangasundara of Arundattaand Ayurvedarasayana of Hemadri: Nidanasthana Chapter 16, verse 20; Varanasi: Krishnadas Academy, 2000: p.530.

10. Bhisagacharya Harishashtri Paradkar Vaidya (Editor), Reprint edition. Ashtanga Hridayam by Vagbhata with commentaries Sarvangasundara of Arundattaand Ayurvedarasayana of Hemadri: Nidanasthana Chapter 15, verse 35; Varanasi: Krishnadas Academy, 2000: p.533.

11. Acharya Jadavji Trikamji (Editor), Revised Edition. Charaka Samhita by Agniveshwith Commentary by Chakrapanidatta: Sidhisthan Chapter 9, verse 6; Varanasi: Chaukhambha Surbharati Prakashan, 2011: p.618.

12. Acharya Jadavji Trikamji (Editor), Revised Edition. Charaka Samhita by Agnivesh with commentary by Chakrapanidatta: Chikitsasthan, Chapter 28, verse 42; Varanasi: Chaukhambha Surbharati Prakashan, 2011: p.618.

13. Acharya Jadavji Trikamji (Editor), Revised Edition. Charaka Samhita by Agnivesh with commentary by Chakrapanidatta: Chikitsasthan, Chapter 28, verse 223, Varanasi: Chaukhambha Surbharati Prakashan, 2011: p.626.

14. Bhisagacharya Harishashtri Paradkar (Editor), Reprint edition. Ashtanga Hridayam by Vagbhata with commentaries Sarvangasundara of Arundatta and Ayurvedarasayana of Hemadri: Sharirasthana Chapter 2, verse 52; Varanasi: Krishnadas Academy, 2000: p.383.

15. Bhisagacharya Harishashtri Paradkar Vaidya (Editor), Reprint edition. Ashtanga Hridayam by Vagbhata with commentaries Sarvangasundara of Arundatta and Ayurvedarasayana of Hemadri: Chikitsasthana, Chapter 21, verse 58-61; Varanasi: Krishnadas Academy, 2000: p.726.

16. Bhisagacharya Harishashtri Paradkar (Editor), Reprint edition. Ashtanga Hridayam by Vagbhata with commentaries Sarvangasundara of Arundatta and Ayurvedarasayana of Hemadri: Sutrasthana, Chapter 6, verse 167-168; Vranasi: Krishnadas Academy, 2000: p.120.

17. Acharya JadavjiTrikamji (Editor), Revised Edition. Charaka Samhita by Agnivesh with Commentary by Chakrapanidatta: Chikitsasthan, Chapter 28, verse 239; Varanasi: Chaukhambha Surbharati Prakashan, 2011: p.627.

18. Acharya Jadavji Trikamji (Editor), Revised Edition. Charaka Samhita by Agnivesh with Commentary by Chakrapanidatta: Sidhisthan, Chapter 9, verse 8; Varanasi: Chaukhambha Surbharati Prakashan, 2011: p.718. 